Article

\title{
Proposal to Foster Sustainability through Circular Economy-Based Engineering: A Profitable Chain from Waste Management to Tunnel Lighting
}

\author{
Valentín Molina-Moreno ${ }^{1, *}$, Juan Carlos Leyva-Díaz ${ }^{2}$, Jorge Sánchez-Molina ${ }^{3}$ \\ and Antonio Peña-García ${ }^{4}$ \\ 1 Department of Management, University of Granada, 18071 Granada, Spain \\ 2 Department of Chemical and Environmental Engineering, University of Oviedo, 33006 Oviedo, Spain; \\ jcleyvadiaz@uniovi.es \\ 3 Department of Chemistry, University of Francisco de Paula Santander, San José de Cúcuta 540003, Colombia; \\ Jorgesm@ufps.edu.co \\ 4 Department of Civil Engineering, University of Granada, 18071 Granada, Spain; pgarcia@ugr.es \\ * Correspondence: vmolina2@ugr.es; Tel.: +34-958-249-598
}

Received: 9 November 2017; Accepted: 24 November 2017; Published: 2 December 2017

\begin{abstract}
The increasing demands of infrastructures in terms of energy consumption, raw material demand, greenhouse gas emissions, waste management, treatment of components after their lifetime period, and financial costs are nowadays a serious threat for sustainability. Given that the resources are limited, it is difficult to ensure an accurate level of well-being for future generations. For this reason, new perspectives in design, production and consumption are necessary. In this work, the principles of circular economy are applied to concrete branches of engineering. Departing from a design orientated to new uses after life period of infrastructures, a circular economy-aimed engineering makes possible the connection and mutual profit of such different branches like waste management and tunnel lighting. The benefits in environmental and financial terms are a strong argument in favor of a stronger link between engineering and circular economy.
\end{abstract}

Keywords: sustainability; lighting; waste management; infrastructures; energy savings; raw materials; $\mathrm{CO}_{2}$ emission; circular economy

\section{Introduction}

Engineering has traditionally followed a linear pattern based on design-production-use-waste. This pattern has been especially pronounced in the construction sector, where the use of raw materials and low percentage of use for the new lives of products (buildings, infrastructures, etc.) has generated a huge amount of waste, the management of which is a major concern for the authorities around the world [1-3]. This concern with waste management comes from the well-known harmful effects of some substances on human health and the environment, and the increasing shortage of some raw materials absolutely necessary for maintaining the necessary progress rate as it is currently understood. This problem does not happen only in construction, but also in other fields of engineering. Mercury and lead from light sources are a good example in lighting technology and electrical engineering [4].

All these factors clearly highlight the necessity of moving towards circular patterns in engineering and construction. If we think in economical terms, we could say that the classical linear economy is unsustainable from financial, environmental and energetic perspectives.

An early approach to circular economy was presented in 1966 in the report "Economics of the Coming Spaceship Earth". Departing from these principles, a formal definition of circular economy can be given. According to the Ellen MacArthur Foundation, "The circular economy refers to an industrial 
economy that is restorative by intention and design. It aims to enable effective flows of material, energy, labor and information so that natural and social capital can be rebuilt. It seeks to reduce energy use per unit of output and accelerate the shift to renewable energy by design, treating everything in the economy as a value resource" [5].

The central idea in circular economy is offering a service during the whole life of a product in such a way the product or some of its parts can be used for other purpose, i.e., other infrastructures, after its original one [6]. In this way, waste is reduced, the use of raw materials is limited, and the energy and $\mathrm{CO}_{2}$ emissions necessary for recycling and manufacturing are minimized.

Since the theoretical background of circular economy is not the focus of this work, some considerations for its application can be found in the extensive literature on the topic, such as the preceding references, or others, such as $[7,8]$.

Before presenting the proposal resulting from this work, the main (but not only) concepts of a circular economy-aimed engineering will be briefly presented in the following paragraphs.

\subsection{Design Stage and Choice of Materials}

The design of a product or infrastructure will determine its entire life cycle, and even what will happen once it has reached the end of its lifetime period. For this reason, the Life Cycle Assessment has become a matter of active research in the field of construction $[9,10]$. The monolithic design of infrastructures makes it very difficult to deconstruct them, and to use any of their parts in future. Even if deconstruction were possible, it could be so demanding in terms of work, energy consumption and even safety that it may not be profitable. For this reason, some works recommend the design of modular products to facilitate deconstruction and, hence, the reuse of some of their parts [7].

Another important item is the choice of materials, which has become the link between the design and construction phase. According to the Ellen MacArthur Foundation, materials can be classified into two different groups: biological materials that, after use, return to biosphere to become nutrients [5]; and technical materials, which are not biodegradable, and must be recycled to become technological nutrients [11].

One critical step is the proper traceability of the materials; that is, the necessity of providing information about materials to know the possibilities of their reuse and recycling. This allows the recognition and separation of components and materials [12]. Every link in the supply chain has access to it from any location [8]. This is extremely important for recovery and new uses, because proper traceability allows the reduction of waste [13].

In addition, an accurate choice of the materials to be used in infrastructures can reduce emissions, reduce the spilling of hazardous materials during recycling and, mainly, facilitate good planning for future uses.

\subsection{Considerations at the Construction Stage}

Many materials used in construction can be recycled or reused, including concrete, bricks, wood, steel, and plastic [14]. Buildings are generally designed to be constructed, but not deconstructed, which makes it difficult and expensive to separate the different components for new uses.

A good treatment of waste to obtain technological nutrients to be reused for other purposes [5] can save money, energy and greenhouse gas emissions. This is one of the main targets of a new engineering based on circular economy.

For example, in the production of clay bricks, coal fly-ash is generated in the process of burning, and only $75 \%$ of the coal is burned [15]. The rest is coal fly-ash, which is easily moved by wind and, if it is not well treated, can affect air quality [16]. For this coal fly-ash, it is convenient to find other purposes. Some utilizations include the following:

- Adding it into material to produce colored bricks, so that the fly-ash becomes part of the loop as input [17]. Moreover, the colored bricks will be sold more expensively, generating added value.

- $\quad$ In the cement industry, since it improves the fireproofing capability [17]. 


\subsection{Considerations during Infrastructure Working}

The sustainability and profitability of infrastructures are not limited to efficient constructions with a good management of the waste. Instead, it is after the design and construction that the life of the infrastructures, as suppliers of services, starts.

At this stage, two factors are especially important: energy consumption of the infrastructure installation and maintenance.

In some infrastructures, like electrical, lighting, or factories, the energy consumption after a relatively short period can greatly exceed the construction costs of the whole infrastructure. For instance, as shown in the proposal of this work, the costs of the energy consumed by the lighting installation of one tunnel can easily reach $1 \mathrm{M} €$ /year. In addition, this problem goes beyond energy itself; the emissions released during energy production, conversion and transportation are really remarkable, whereas the raw materials used for the construction of such consuming installations have a deep impact on the preservation of natural resources.

Concerning maintenance, the cost in critical infrastructures like roads, tunnels, mines and factories are also in the millions. In addition, the impact on workers' safety is an issue of major concern [18].

Hence, engineering based on circular economy must start with smart design, leading to sustainable construction and later deconstruction from all perspectives, but also to a sustainable and profitable working during the lifetime of the infrastructure.

The purpose of the work is double: on one hand, it aims to show that different branches of engineering can be orientated according to the principles of circular economy by transforming their waste into technological nutrients and implementing smart designs respectively (Section 2); on the other hand, it is demonstrated that one orientation based on circular economy can link apparently far fields, converting the waste of one in the nutrient of the second, and vice versa (Section 3).

\section{Proposal of Circular Economy-Based Engineering Linking Different Sectors}

Although the fields of application of engineering based on the principles of circular economy are remarkably numerous, this section presents a proposal linking three critical sectors in which the shift towards "circular economy-minded" engineering powerfully fosters sustainability.

In this case, we commence with water treatment and, going through the principles of circular design described above (modular design, deconstruction, etc.), a second life in the field of sunlight use in tunnels is found. Then, there is a loop that starts again with the tunnel deconstruction.

The sectors involved in this example and their impact on energy and consumption of raw materials, greenhouse gas emissions, financial costs and, in summary, global sustainability, is nowadays a real challenge [19].

\subsection{Water Treatment: Sewage Sludge}

In recent years, the amount of sewage sludge from drinking water treatment plants (DWTPs) is growing in Europe. Sewage sludge is generated in the phases of settling and filtration, as can be seen from Figure 1, which shows a diagram of a DWTP. In this regard, it is necessary to manage this waste in order to comply with European legislation.

The Directive 99/31/EC [20] was intended to reduce the possibility of disposing the sewage sludge in landfills, as previously had been done [19]. In light of this, the incineration of sewage sludge is a frequently used valorization method. The ash obtained in the incineration process can contain various compounds, such as $\mathrm{SiO}_{2}, \mathrm{CaO}, \mathrm{Al}_{2} \mathrm{O}_{3}, \mathrm{Fe}_{2} \mathrm{O}_{3}, \mathrm{MgO}$ and $\mathrm{P}_{2} \mathrm{O}_{5}$, favoring its use in the construction sector as aggregate, concrete, supplementary cementing materials, blended cement, bricks, tiles, blocks, wall panels, roof sheets, reinforced polymer composites, etc. [21,22].

On the whole, the most common applications are cement production, brick production, ceramic and glass production, and road construction [23]. Many authors have studied the use of sewage sludge from a DWTP to produce ceramic materials for the construction sector [24] and to partially substitute 
the clay in the manufacturing of bricks [25,26], as well as the production of Portland cement [27]. It should be highlighted that the most favorable rations of ash are $10 \%$ substitution of cement and $2 \%$ substitution of sand [28].

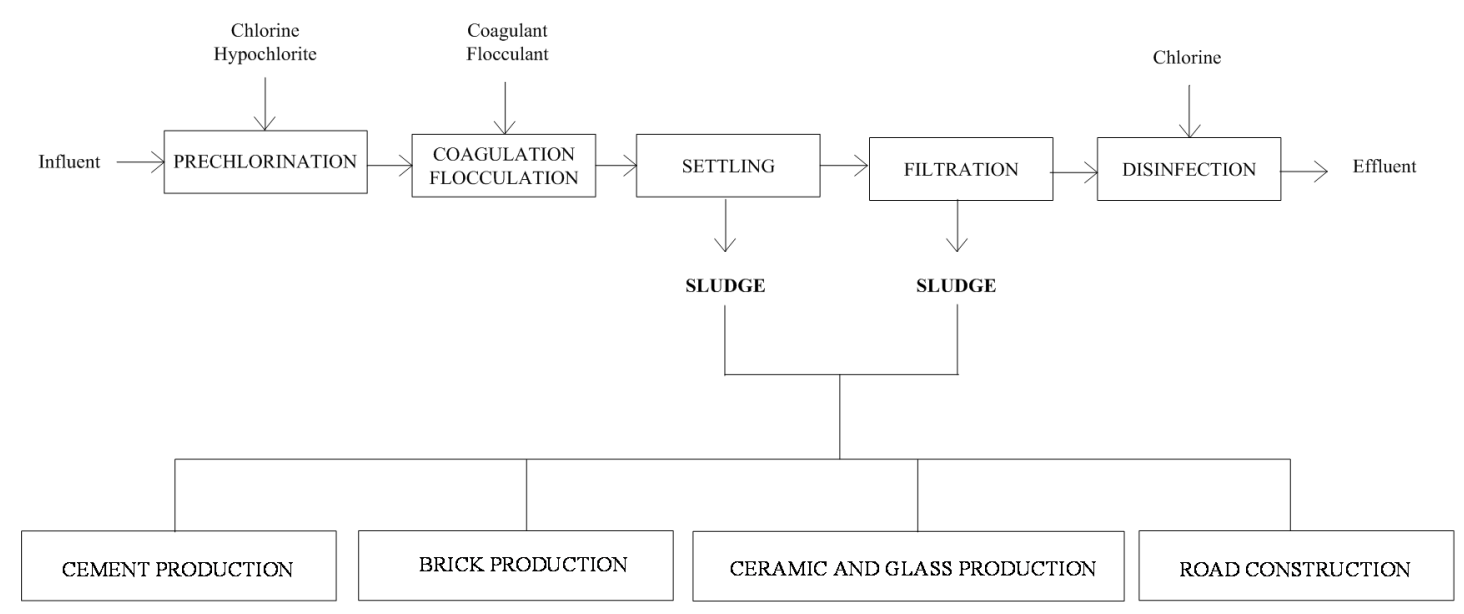

Figure 1. Schematic diagram of a Drinking Water Treatment Plant with the applications of the sewage sludge.

In this regard, the use of incinerated sewage sludge ash could have potential disadvantages with regard to its future applications in brick manufacturing, as the increase of tempering water required could raise the drying costs, and the addition of an anti-scum agent could increase the production costs [29]. Despite these drawbacks, this does not disqualify this sustainable approach when assessing the possible trade-off between cost and sustainability.

This use of the sewage sludge enables the cost of the sludge treatment to be decreased, and the transfer of ash to the environment to be reduced. Therefore, sewage sludge is converted into a technological nutrient that can be reintroduced in the construction sector within the paradigm of the circular economy.

\subsection{Lighting Infrastructures: Use of Sunlight in Road Tunnels}

Road tunnels are infrastructures whose impact on safety is really critical. Due to their singularity, and some characteristics of the human visual system, their lighting installations must supply very high rates of luminous flux, especially during daytime, in order to ensure the visual adaptation of drivers entering from bright environments [30]. The impact of these levels of illumination in financial terms can reach $1 \mathrm{M} €$ /year per tunnel in many cases. In addition, a single not-very-long tunnel must incorporate hundreds of projectors, which means a remarkable consumption in raw materials (lamps, wiring, aluminum), human resources due to the intensive maintenance and, of course, energy.

In recent years, research groups around the world have focused their efforts on the development of strategies to introduce natural light inside the tunnels [31-33], or to shift the threshold zone, which is the most consuming part, out of the tunnel, using a part of the sunlight, properly filtered and attenuated [34-39]. The most promising strategy in this last case is the use of pre-tunnel pergolas, whose construction before the portal gate can yield energy savings in the threshold zone of about $40 \%$ [35]. The use of pergolas with the intention only of saving energy has been already introduced in real tunnels, like the one in Figure 2.

It is also remarkable that the efforts to decrease the huge economic, environmental and energy consumption of the lighting installations of tunnels have included forestation of portals, which simultaneously contributes to the stability of the mountainside [40]; special devices to regulate the luminous flux [41]; and special pavements to improve road reflectance, resulting in a subsequent decrease in the installed power [42,43]. 


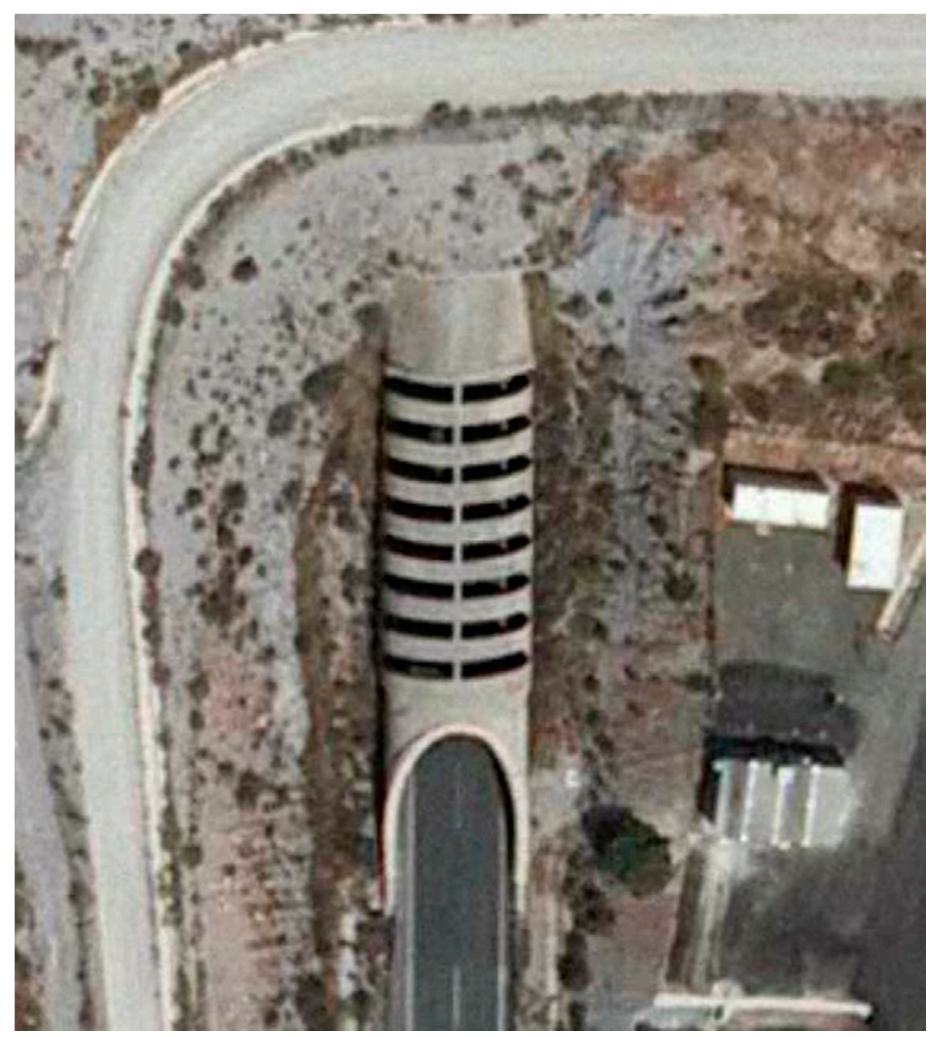

Figure 2. Concrete pergola at the portal gate of one road tunnel in Lorca (Spain). Taken from [33].

Thus, this scenario, in which radically new lighting installations are under planning in tunnels, is an excellent opportunity to introduce the principles of circular economy into the main phases of the product life: design, construction, working and recycling.

A new and sustainable tunnel would incorporate systems to use sunlight, solar panels or other technologies in the exterior of the tunnel to power the electrical devices (such as luminaries, ventilation or emergency light), special pavements, appropriate vegetation to decrease energy demands, etc.

However, beyond these elements, the design would be cognizant of the end of life from the very beginning. For this reason, the following proposals are presented:

- $\quad$ Structures to use sunlight by shifting the most consuming zone, like classical pergolas or structures [29-31], should be constructed with cement originating from the treatment of sewage sludge, as seen in the preceding section. This is possible because these structures do not have to support heavy loads; their mission is just the filtering of natural light.

- The design and construction of these structures must always keep in mind their next lives. Hence, a modular design to enable their deconstruction, transport, and use, if the tunnel is ever remodeled, is appropriate.

- The pavement, whose accurate reflectance decreases energy consumption, will be chosen from among those incorporating waste from other products [44], which will be considered as a technological nutrient. Once more, sewage sludge can be used as a component of the cement whenever their reflective properties are appropriate.

- The vegetation chosen to forest the mountainside will be perennial and, in addition, species will be sought that are appropriate for clean combustion, should they need to be removed.

- Other structures for the use of sunlight, like mirrors or light-pipes, will also be modular, so that they can be used in other buildings once their life period in the tunnel is over. 
- Devices with hazardous materials, like LED projectors, will also be modular, so that demounting at the end of their life easily allows the separation of reusable components from those needing other kinds of treatment.

These simple actions will contribute to sustainability, but also to safety, because bad designed lighting installations usually require careful maintenance, which, in tunnels, is especially dangerous for drivers and operators.

\section{Circular Economy as Driving Force for a Global Engineering}

An overall glance at these measures for deecreasing energy and material consumption, as well as enhancing benefits, shows that the design and construction of products and infrastructure that operates following the principles of circular economy can lead to a global engineering where different areas are not disconnected anymore, but rather are strongly linked.

Indeed, most projects are currently aimed at the necessities of the installation under design or construction by fulfilling the requirements of the applicable standards and regulations. This way to do things, so strongly based in the classical principles of the linear model "take, make and dispose" [5], might lead to an incorrect perception of areas in engineering being isolated. In such a linear model, the dependence between different areas is hierarchical and vertical.

In the study case of sewage sludge and use of sunlight in tunnels, a relatively sustainable linear model may foster the use of the cements originating from waste to manufacture pergolas, and profit from natural light in tunnels. However, nothing is foreseen for these pergolas once their lifetime period is over, or the tunnel is not used anymore (due to the construction of an alternative or better highway, for example). It is smart design, orientated to the future use of the cement columns, that will make them a technological nutrient for the deconstruction sector, whose waste could return to sewage sludge treatment again and so on.

In this case, the relationship with the other sectors is represented in Figure 3.

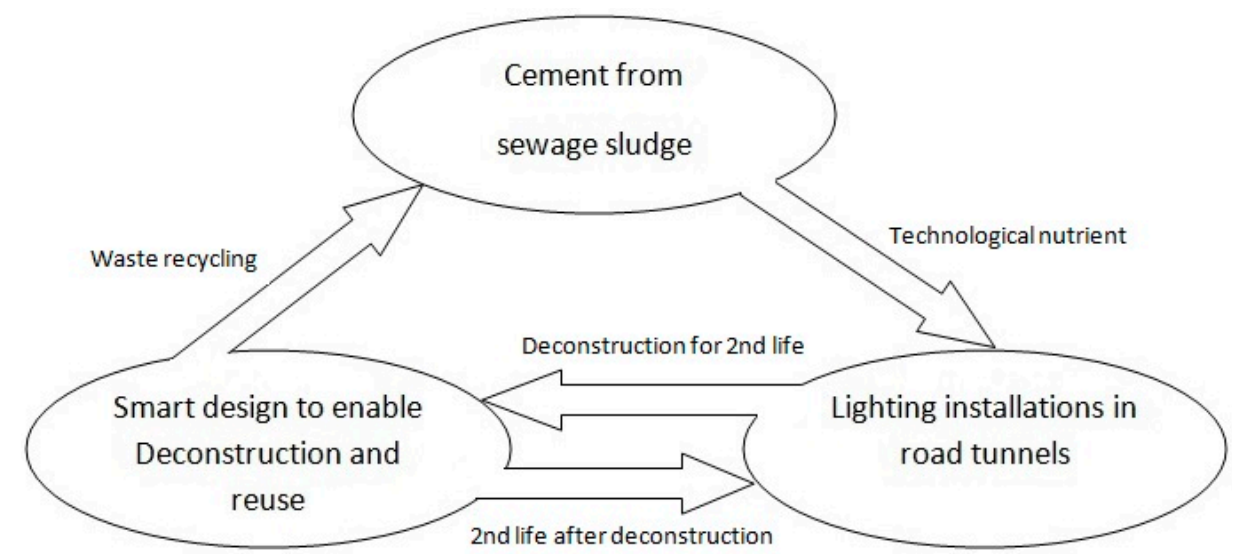

Figure 3. Feedback between three critical sectors when engineered according to the principles of circular economy.

As shown, three apparently remote sectors have been linked, and a positive feedback among them has been found when considering the phases of design, construction, working and recycling from the integrative perspective of circular economy.

Hence, engineering based on circularity will necessarily be global; designers and manufacturers will not think exclusively of their product anymore, but will necessarily develop a broader vision. Such vision must go along all the links in the chain, from basic science to final sales. Of course, the new panorama is more demanding for scientists, engineers, manufacturers, and even marketing experts, but the positive effects of such way of thinking clearly outweigh the intellectual cost of the challenge. 
The profits in financial, energetic, and material use, as well as with respect to the environment, result in more sustainable infrastructures and a more sustainable society, preserving resources for future generations, as recommended by the Brundtland Report [45].

\section{Conclusions}

Circular economy is more than a model for producing benefits. The application of its principles to engineering produces powerful synergies whose main consequence is an important improvement in sustainability in environmental, energetic and financial terms.

The application of these principles does not consider waste as a side effect of progress, but as an opportunity to keep on growing without risking natural resources for future generations. The design is not exclusively focused on functionality, but goes beyond that, and tries to foresee how the end of life of products and infrastructures will be, as well as the opportunities for components or whole products to become part of new infrastructures or production chains.

Anyhow, the path towards circular economy is not easy, and the involvement of administrations and supranational bodies is necessary.

One illustrative case, the complex relationship involving three different sectors (water management, deconstruction and lighting infrastructures), has been presented. This shows how engineering can be considered almost as a whole when different areas are linked through the principles of circular economy. Thus, the necessary concrete to build pergolas, which are currently employed to use sunlight inside road tunnels, can come from sewage sludge, whose quality is optimal. Even if this concrete were not so strong, there would be no problem, because these pergolas do not support heavy loads. In addition, a modular design for the pergolas could facilitate their deconstruction and transportation once their lifetime is over. The parts of the pergolas could be used later for other purposes, with zero waste and energy consumption other than that required to transport them to their new location.

In summary, the necessary shift to circular economy-aimed engineering will create new opportunities in the near future, when some shocking concepts like technological nutrients, waste as food or design for next lives will be synonymous with global engineering for a more sustainable world.

Acknowledgments: This study has been supported and co-financed by projects from the Spanish Ministry of Economy and Competitiveness ECO2010-15885 and ECO2013-47027-P, Andalusian Government P11-SEJ-7294 and European Union (ERDF funds).

Author Contributions: All authors participated equally in the conception, design and elaboration of this work. All authors read and approved the final manuscript.

Conflicts of Interest: The authors declare no conflict of interest.

\section{References}

1. Miccoli, S.; Finucci, F.; Murro, R. Criteria and Procedures for Regional Environmental Regeneration: A European Strategic Project. Appl. Mech. Mat. 2014, 675-677. [CrossRef]

2. Akanbi, L.A.; Oyedele, L.O.; Akinade, O.O.; Ajayi, A.O.; Davila Delgado, M.; Bilal, M.; Bello, S.A. Salvaging building materials in a circular economy: A BIM-based whole-life performance estimator. Res. Conserv. Recycl. 2018, 129, 175-186. [CrossRef]

3. Iacovidou, E.; Velis, C.A.; Purnell, P.; Zwirner, O.; Brown, A.; Hahladakis, J.; Millward-Hopkins, J.; Williams, P.T. Metrics for optimising the multi-dimensional value of resources recovered from waste in a circular economy: A critical review. J. Clean. Prod. 2017, 166, 910-938. [CrossRef]

4. Montoya, F.G.; Peña-García, A.; Juaidi, A.; Manzano-Agugliaro, F. Indoor Lighting Techniques: An overview of evolution and new trends for energy saving. Energy Build. 2017, 140, 50-60. [CrossRef]

5. Ellen MacArhtur Foundation. Towards the Circular Economy, Economic and Business Rationale for an Accelerated Transition; Ellen MacArhtur Foundation: Cowes, UK, 2013. 
6. Alizadeh, J. Circular Economy and Civil Infrastructure Systems Applying the Principles of Circular Economy into the Design and Engineering Process of the Civil Infrastructure Systems. Master's Dissertation, Eindhoven University of Technology, Eindhoven, The Netherlands, 2016.

7. Waste \& Resources Action Programme. Designing out Waste: A Design Team Guide for Buildings; Institute of Civil Engineers (ICE): London, UK, 2012.

8. Sánchez, A. A Shift in the Construction sector: Towards a Circular Economy. Master's Dissertation, University of Granada, Granada, Spain, 2017.

9. Moretti, L.; Mandrone, V.; D'Andrea, A.; Caro, S. Comparative "from cradle to gate" Life Cycle Assessments of Hot Mix Asphalt (HMA) Materials. Sustainability 2017, 9, 400. [CrossRef]

10. Moretti, L.; Caro, S. Critical analysis of the Life Cycle Assessment of the Italian Cement Industry. J. Clean. Prod. 2017, 152, 198-210. [CrossRef]

11. Molina-Moreno, V.; Leyva-Díaz, J.C.; Sánchez-Molina, J. Pellet as a Technological Nutrient within the Circular Economy Model: Comparative Analysis of Combustion Efficiency and $\mathrm{CO}$ and $\mathrm{NO}_{\mathrm{x}}$ Emissions for Pellets from Olive and Almond Trees. Energies 2016, 9, 777. [CrossRef]

12. Damen, M.A. A Resources Passport for a Circular Economy. Master's Thesis, Utrecht University, Utrecht, The Netherlands, 2012.

13. Ellen MacArthur Foundation. Circularity in the Built Environment: Cases Studies. A Compilation of Cases Studies from the CE100. 2016. Available online: https://www.ellenmacarthurfoundation.org/assets/ downloads/Built-Env-Co.Project.pdf (accessed on 1 December 2017).

14. European Circular Construction Alliance. Adopting Circular Economy for Internationalization and Global Competitiveness of European SMEs in Building and Construction. 2016. Available online: https://www.clustercollaboration.eu/sites/default/files/profile-article/European\%20Circular\% 20Construction\%20Aliance\%20-\%20in\%20brief\%20-\%20ver.\%20Feb\%202016.pdf (accessed on 1 December 2017).

15. Bautista, J. Optimización de la Operación de Secado de Tableta y Enfriamiento de Tableta y Bloque en Cerámicas Támesis S.A. Ph.D. Thesis, University of Francisco de Paula Santander, San José de Cúcuta, Colombia, 2002.

16. Huang, X. Environmental damage and new uses technology of fly-ash. Guangdong Chem. Ind. 2007, 34, 77.

17. Liu, H.; Liu, Z. Recycling utilization patterns of coal mining waste in China. Resour. Conserv. Recy. 2010, 54, 1331-1340. [CrossRef]

18. Moretti, L.; Di Mascio, P.; Bellagamba, S. Environmental, Human Health and Socio-Economic Effects of Cement Powders: The Multicriteria Analysis as Decisional Methodology. Int. J. Environ. Res. Publich Health 2017, 14, 645. [CrossRef] [PubMed]

19. Molina-Moreno, V.; Leyva-Díaz, J.C.; Llorens-Montes, F.J.; Cortés-García, F.J. Design of indicators of circular economy as instruments for the evaluation of sustainability and efficiency in wastewater from pig farming industry. Water 2017, 9, 653. [CrossRef]

20. Council Directive 99/31/EC of 26 April 1999 on the Landfill of Waste. Available online: eur-lex.europa.eu / legal-content/EN/TXT/?uri=celex\%3A31999L0031 (accessed on 1 December 2017).

21. ARUP. The Circular Economy in the Built Environment. 2016. Available online: https:/ /www.arup.com/ - / media/arup / files / publications / c circular-economy-in-the-built-environment-270916.pdf (accessed on 1 December 2017).

22. Lin, Y.; Zhou, S.; Li, F.; Lin, Y. Utilization of municipal sewage sludge as additives for the production of eco-cement. J. Hazard. Mater. 2012, 213, 457-465. [CrossRef] [PubMed]

23. Smol, M.; Kulczycka, J.; Henclik, A.; Gorazda, K. The possible use of sewage sludge ash (SSA) in the construction industry as a way towards a circular economy. J. Clean. Prod. 2015, 95, 45-54. [CrossRef]

24. Cerdeño del Castillo, F.J.; Pérez Lorenzo, A. Viabilidadtécnica de uso de lodos de Estaciones de Tratamiento de Aguas Potables (ETAP) en fabricación de materialescerámicospara la construcción. Conarquitectura 2006, 30, 89-96.

25. Argudo-García, J.; Molina-Moreno, V.; Leyva-Díaz, J.C. Valorización de lodosprocedentes de plantas de tratamiento de agua potable. Unaapuestapor la economía circular y sostenibilidad. Dyna 2016, 92, 71-75. [CrossRef]

26. Pereira, D.A.; Couto, D.M.; Labrincha, J.A. Incorporation of alumina rich residues in refractory bricks. CFI-Ceram. Forum Int. 2000, 77, 21-25.

27. Elías Castells, X. Reciclaje de ResiduosIndustriales; EdicionesDíaz de Santos: Madrid, Spain, 2009. 
28. Chen, M.; Blanc, D.; Gautier, M.; Mehu, J.; Gourdon, R. Environmental and technical assessments of the potential utilization of sewage sludge ashes. Waste Manag. 2013, 33, 1268-1275. [CrossRef] [PubMed]

29. Anderson, M. Encouraging prospects for recycling incinerated sewage sludge ash (ISSA) into clay-based building products. J. Chem. Technol. Biotechnol. 2002, 77, 352-360. [CrossRef]

30. Commission Internationale de l'Éclairage, CIE. Guide for the Lighting of Road Tunnels and Underpasses; CIE Publications: Vienna, Austria, 2004; p. 88.

31. Gil-Martín, L.M.; Peña-García, A.; Jiménez, A.; Hernández-Montes, E. Study of Light-pipes for the use of sunlight in road tunnels: From a scale model to real tunnels. Tunn. Undergr. Space Technol. 2014, 41, 82-87. [CrossRef]

32. Qin, X.; Zhang, X.; Qi, S.; Han, H. Design of Solar Optical Fiber Lighting System for Enhanced Lighting in Highway Tunnel Threshold Zone: A Case Study of Huashuyan Tunnel in China. Int. J. Photoenergy 2015, 2015, 1-10. [CrossRef]

33. Peña-García, A.; Gil-Martín, L.M.; Hernández-Montes, E. Use of sunlight in road tunnels: An approach to the improvement of light-pipes' efficacy through heliostats. Tunn. Undergr. Space Technol. 2016, 60, 135-140. [CrossRef]

34. Gil-Martín, L.M.; Peña-García, A.; Hernández-Montes, E.; Espín-Estrella, A. Tension structures: A way towards sustainable lighting in road tunnels. Tunn. Undergr. Space Technol. 2011, 26, 223-227. [CrossRef]

35. Peña-García, A.; Gil-Martín, L.M. Study of pergolas for energy savings in road tunnels. Comparison with tension structures. Tunn. Undergr. Space Technol. 2013, 35, 172-177. [CrossRef]

36. Gil-Martín, L.M.; Gómez-Guzmán, A.; Peña-García, A. Use of diffusers materials to improve the homogeneity of sunlight under pergolas installed in road tunnels portals for energy savings. Tunn. Undergr. Space Technol. 2015, 48, 123-128. [CrossRef]

37. Drakou, D.; Burattini, C.; Bisegna, F.; Gugliermetti, F. Study of a daylight "filter" zone in tunnels. In Proceedings of the IEEE 15th International Conference on Environment and Electrical Engineering (EEEIC), Rome, Italy, 10-13 June 2015; pp. 649-652.

38. Drakou, D.; Celucci, L.; Burattini, C.; Nardecchia, F.; Gugliermetti, F. Study for optimizing the daylight "filter" in a pre-tunnel structure. In Proceedings of the IEEE 16th International Conference on Environment and Electrical Engineering (EEEIC), Florence, Italy, 6-8 June 2016; p. 4.

39. Drakou, D.; Burattini, C.; Mangione, A.; Bisegna, F. Exploring the daylight simulation of filter panels in a pre-tunnel structure. In Proceedings of the 2017 IEEE International Conference on Environment and Electrical Engineering and 2017 IEEE Industrial and Commercial Power Systems Europe (EEEIC/I\&CPS Europe), Milan, Italy, 6-9 June 2017; pp. 1-5.

40. Peña-García, A.; López, J.C.; Grindlay, A.L. Decrease of energy demands of lighting installations in road tunnels based in the forestation of portal surroundings with climbing plants. Tunn. Undergr. Space Technol. 2015, 46, 111-115. [CrossRef]

41. Salata, F.; Golasi, I.; Poliziani, A.; Futia, A.; de LietoVollaro, E.; Coppi, M.; de LietoVollaro, A. Management Optimization of the Luminous Flux Regulation of a Lighting System in Road Tunnels. A First Approach to the Exertion of Predictive Control Systems. Sustainability 2016, 8, 1092. [CrossRef]

42. Salata, F.; Golasi, I.; Bovenzi, S.; de LietoVollaro, E.; Pagliaro, F.; Cellucci, L.; Coppi, M.; Gugliermetti, F.; de LietoVollaro, A. Energy Optimization of Road Tunnel Lighting Systems. Sustainability 2015, 7, 9664-9680. [CrossRef]

43. Moretti, L.; Cantisani, G.; Mascio, P.D. Management of road tunnels: Construction, maintenance and lighting costs. Tunn. Undergr. Space Technol. 2016, 51, 84-89. [CrossRef]

44. D'Andrea, A.; Bonora, V.; Drago, D. Asphalt concrete with bottom ash: Environmental aspects. In Proceedings of the International Conference on Restoration, Recycling and Rejuvenation Technology for Engineering and Architecture Application, Cesena, Italy, 7-11 June 2004.

45. World Commission on Environment and Development. Our Common Future. 1987. Available online: http:/ / www.un-documents.net/our-common-future.pdf (accessed on 1 December 2017).

(C) 2017 by the authors. Licensee MDPI, Basel, Switzerland. This article is an open access article distributed under the terms and conditions of the Creative Commons Attribution (CC BY) license (http:/ / creativecommons.org/licenses/by/4.0/). 